\title{
Evaluasi Kinerja Perusahaan Minyak Kelapa Sawit PT. Astra Argo Lestari Tbk. (AALI) dan PT. PP London Sumatra Indonesia Tbk (LSIP)
}

\author{
Wendra Hartono ${ }^{1}$ \\ ${ }^{1}$ Universitas Ciputra Surabaya \\ wendra.hartono@ciputra.ac.id
}

DOI: https://doi.org/10.24071/exero.v2i2.4046

\begin{abstract}
Abstrak
Pergerakan harga saham di perusahaan perkebunan minyak kelapa sawit sangat menarik untuk ditinjau sebagai obyek penelitian. Ini disebabkan oleh fluktuasi permintaan dan permintaan yang menyebabkan harga melambung tinggi atau jatuh dalam jangka waktuy sekitar 60\% dalam waktu kurang dari 2 tahun. Penelitian ini akan membahas kinerja perusahaan kelapa sawit menggunakan tiga pendekatan analisis seperti fundamental dan teknis dan faktar internal dan eksternal yang dapat mempengaruhi kinerja perusahaan dalam membuat keputusan dan laporan keuangan. Studi ini bertujuan untuk mengevaluasi kinerja saham LSIP dan AALI sehak tahun 2017-Semester 12019 dan memberikan pertimbangan bagi investor potensial sebelum memutuskan untuk membeli saham LSIP atau AALI. Teknik yang digunakan adalah purposive sampling dengan pendekatan metode kualitatif deskriptif. Hasil dari study ini adalah dua perkebunan minyak kelapa sawit masih mengalami tekanan karena penurunan pasar permintaan dan harga dunia CPOO. Ini akan berdampak pada laporan kuangan, terutama pada resiko keuntungan. Peneliti merekomendasikan membeli saham AALI dibandingkan dengan LSIP untuk jangka waktu yang lama.
\end{abstract}

Kata kunci: minyak kelapa sawit, fundamental, teknikal

\begin{abstract}
The movement of share prices in palm oil plantation companies is very interesting to review as an object of research. This is caused by the fluctuation of supply and demand which causes prices to soar high or fall within a period of approximately $60 \%$ in less than 2 years. This research will discuss the performance of oil palm companies using three analytical approaches such as fundamental, technical and internal and external facts that can affect the company's performance in making decisions and financial statements. This study aims to evaluate the performance of LSIP and AALI shares since 2017-Semester 12019 and provide consideration for potential investors before deciding to buy LSIP or AALI shares. The technique used is purposive sampling with a descriptive qualitative method approach. The results of this study are the two oil palm plantation shares are still experiencing pressure due to declining market demand and the eroded world CPO prices. This will have an impact on financial statements, especially on profitability ratios. The author recommends buying AALI stock compared to LSIP for a long period of time.
\end{abstract}

Keywords: palm oil, fundamental, technical

\section{Pendahuluan}

Perusahaan perkebunan kelapa sawit mengalami puncak kejayaannya sejak dari awal tahun 2000 sampai dengan tahun 2007. Hal ini dibuktikan dengan meningkatnya harga CPO dan jumlah permintaan yang tinggi baik dari dalam negeri maupun luar negeri. Permintaan dari luar negeri meningkat jumlahnya terutama dari negara China dan India. Namun sejak tahun 2008, terjadi resesi global yang 
menyebabkan harga-harga komoditas mengalami penurunan termasuk harga CPO (Santosa, 2010). Faktor lain, contohnya cuaca alam yang buruk, dapat juga menjadi faktor kegagalan dalam memproduksi kelapa sawit

Saat ini sudah hampir 10 tahun terakhir sejak tahun 2008 - 2019, harga CPO dunia mengalami fluktuasi yang menyebabkan laporan keuangan perusahaan kelapa sawit juga bergejolak. Berikut adalah grafik fluktuasi harga CPO selama 10 tahun terakhir.

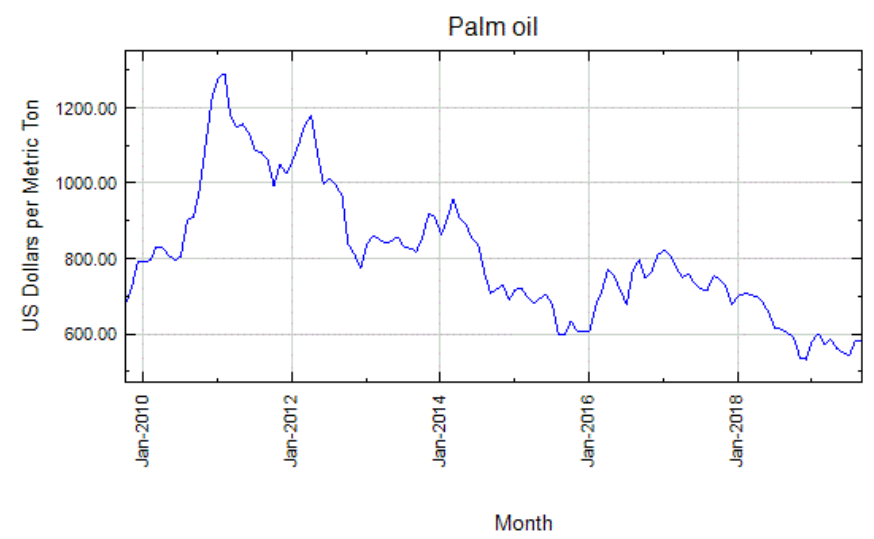

Gambar 1. Pergerakan Harga CPO 10 tahun terakhir Sumber : sahamok.com

Pada Gambar 1. telah ditunjukkan bahwa harga CPO cenderung mengalami penurunan dari nilai tertingginya adalah di kisaran USD1300 per metric ton pada tahun 2011 dan nilai terendah adalah pada tahun 2019 dikisaran USD 540 per metric Ton. Para perusahaan perkebunan harus memikirkan strategi guna mengatasi penurunan laba yang diperolehnya dan juga dalam upaya memenangkan persaingan yang semakin sengit dengan para pesaingnya.

Pada penelitian ini akan diulas dan dievaluasi tentang kinerja laporan keuangan AALI dan LSIP selama 2,5 tahun terakhir. Berdasarkan pemaparan diatas, peneliti ingin melakukan penelitian tentang bagaimana kinerja kedua perusahaan perkebunan kelapa sawit dari sisi laporan keuangan maupun secara teknikal untuk mengetahui pergerakan kedua harga saham ini. Adapun tujuan dari penelitian ini adalah untuk memberikan informasi atau pertimbangan kepada para pembaca atau investor tentang kinerja dua perusahaan perkebunan kelapa sawit terhadap pergerakan harga saham, sebelum para investor membeli saham perkebunan ini. 


\section{Profil Perusahaan}

PT Astra Argo Lestari, Tbk. (AALI) merupakan perusahaan yang bergerak pada bidang perkebunan kelapa sawit sejak tahun 1981. Bisnis utamanya adalah memproduksi dan menjual hasil Crude Palm Oil, yang diperoleh dari pengolahan buah kelapa sawit. Fungsi dari kelapa sawit sendiri adalah untuk bahan dasar minyak goreng, dan alternatif biodiesel. AALI sudah mencatatkan dirinya pada Bursa Efek Indonesia sejak bulan Desember 1997, dan masuk dalam indeks LQ-45.

PT. London Sumatra Indonesia, Tbk. (LSIP) merupakan sebuah perusahaan kelapa sawit yang didirikan sejak tanggal 18 Desember 1962. Perusahaan ini merupakan salah satu anak usaha dari PT. Salim Invomas Pratama Tbk. (SIMP). Perusahaan ini terdaftar sebagai anggota BEI pada tahun 1996, dengan harga nominal sebesar Rp. 500 perlembar saham.

\section{Kajian Literatur}

Dalam penelitian ini, peneliti akan melakukan evaluasi kinerja laporan keuangan terhadap pergerakan harga saham dengan menggunakan tiga pendekatan analisis, yang meliputi analisis fundamental, teknikal, serta berita yang berisi tentang fakta internal maupun eksternal yang dapat mempengaruhi laporan keuangan perusahaan AALI dan LSIP.

\section{Analisis Fundamental}

Analisis fundamental sangat erat kaitannya dengan mengkaji laporan keuangan perusahaan, dengan memperhitungkan rasio-rasio keuangan guna mempermudah dalam pendeskripsian data. Menurut Corrado (2002:153) mengatakan bahwa analisis fundamental merupakan suatu pemeriksaan laporan keuangan suatu perusahaan dan keuangan lainnya dan informasi ekonomi untuk menilai pergerakan harga saham.

Rasio keuangan yang akan dibahas dalam penelitian ini terdiri dari :

1. Profitability ratio, contohnya return on asset (ROA), return on equity (ROE), Net Profit Margin,

2. Solvability ratio, contohnya debt equity ratio (DER)

3. Measurement ratio, contohnya price earnings ratio (PER), dividend payout ratio $(D P R)$ dan, dividend yield. 
Menurut Heri (2017:143) rasio profitabilitas digunakan untuk menggambarkan kemampuan perusahaan dalam mendapatkan keberhasilan laba. Sebagai contohnya adalah rasio tingkat pengembalian atas investasi, yaitu Return on asset (ROA) dan Return on Equity (ROE). ROA adalah sebuah rasio yang menunjukkan hasil terhadap pemakaian harta perusahaan dalam menghasilkan laba bersih. Return on equity (ROE) adalah suatu rasio yang mengukur hasil (return) atas pemakaian ekuitas perusahaan dalam memperoleh laba bersih. Net Profit Margin (NPM) merupakan contoh dari rasio kinerja operasi yang masih tergolong dalam rasio profitabilitas. NPM didefinisikan sebagai rasio yang dipakai untuk menghitung besarnya nilai persentase laba kotor atas penjualan bersih.

Menurut Heri (2017:142) menjelaskan rasio solvabilitas sebagai sebuah perbandingan angka yang menunjukkan hasil dari pengukuran suatu kemampuan perusahaan dalam membayar seluruh kewajibannya. Salah satu contoh rasio solvabilitas yang digunakan dalam penelitian ini adalah Debt to Equity Ratio (DER), yang merupakan sebuah rasio yang mengukur nilai banding antara jumlah total utang dengan modal. Hal ini digunakan oleh kreditor untuk menganalisis perusahaan ketika ingin meminjam kredit atau resiko keuangan.

Measurement value ratio adalah sebuah rasio yang dipakai untuk mengestimasi nilai dari intrinsik suatu perusahaan. Menurut Kang (2009:215) PER adalah sebuah rasio yang menghitung harga pasar dari setiap saham biasa terhadap pendapatan per lembar sahamnya. Dividend Payout Ratio (DPR) adalah sebuah rasio yang mengukur persentase laba yang di distribusikan kedalam bentuk dividen tunai. Sedangkan dividend yield adalah sebuah rasio yang menunjukkan hasil nilai perbandingan cash dividend per lembar saham dengan harga pasar.

\section{Analisis Teknikal}

Definisi analisis teknikal menurut Tandelilin (2010:392) adalah sebuah analisis dengan menggunakan berbagai indikator dengan menggunakan harga penutupan saham di waktu-waktu sebelumnya sebagai objeknya. Indikator analisis teknikal ini berupa garis trend yang digunakan untuk memprediksi pergerakan harga saham yang sifatnya jangka pendek, yang berbentuk grafik. 
Pada penelitian ini akan digunakan dua jenis indikator yaitu Leading dan Lagging indicators. Menurut Ong (2008:47) mengatakan bahwa leading indicators merupakan sebuah faktor ekonomi yang mampu merubah keadaan sebelum faktor ekonomi lainnya mulai beranjak pergi ke momentum tertentu. Dalam perdagangan saham istilah leading indicator, digunakan untuk mengetahui apakah harga saham berada dalam harga tertinggi (overvalued) atau terendah (undervalued), sebagai salah satu contohnya adalah Relative Strength Index (RSI). Sedangkan Menurut James Chen (2018) dalam Investopedia menjelaskan lagging indicators adalah sebuah alat yang digunakan untuk mengukur dan menilai trend atau pola tertentu sebagai dampak dari hasil data-data pergerakan harga saham penutupan sebelumnya, contohnya adalah garis Moving Average (MA).

\section{Fakta dan Kebijakan Perusahaan}

Berita merupakan salah satu media yang dapat menggerakkan harga saham. Berita yang tersiar meliputi berbagai macam kegiatan baik yang berasal dari internal maupun eksternal. Faktor internal yang meliputi aksi korporasi, sebagai contohnya adalah aksi pembelian saham kembali (buyback), penerbitan obligasi, pembagian dividen dan lain sebagainya. Sedangkan faktor eksternal yang meliputi kegiatan yang diluar kontrol perusahaan, sebagai contohnya adalah adanya kebijakan pemerintah, perubahan peraturan dunia secara global, dampak perang dagang antara China dan Amerika dan lain sebagainya. Setiap berita yang disiarkan ke media, akan memberikan dampak positif maupun negatif terhadap pergerakan harga saham.

\section{Metode Penelitian}

Populasi dalam penelitian ini adalah perusahaan multinasional dalam subsector perkebunan minyak kelapa sawit yang sudah tercatat dalam lantai bursa saham sejak tahun 2017-2019. Teknik yang digunakan dalam penelitian ini adalah purposive sampling, dimana peneliti sudah menentukan kriteria sampel terlebih dahulu. Adapun kriteria sampel adalah sebagai berikut :

1. Perusahaan multinasional yang tergabung dalam subsector perkebunan minyak kelapa sawit yang tercatat dalam Bursa Efek Indonesia.

2. Perusahaan tersebut mampu memberikan laporan keuangan kepada public secara lengkap dan terus-menerus selama tahun 2017-2019. 
3. Perusahaan memberikan dividen secara rutin setiap tahun kepada para pemegang saham biasa.

Berdasarkan tiga kriteria tersebut terpilih AALI dan LSIP sebagai sampel. Sumber data yang digunakan adalah data sekunder. Data sekunder diperoleh dari berbagai macam referensi seperti buku, artikel koran daring, laporan keuangan, dan jurnal keuangan sejak tahun 2017 sampai dengan 2019. Semua referensi tersebut telah didokumentasikan untuk diambil dan diolah datanya dan kemudian ditulis dalam karya ilmiah.

Pada penelitian ini, peneliti menggunakan metode kualitatif deskriptif. Menurut Supardi (2005:75) menjelaskan bahwa sebuah penelitian deskriptif merupakan sebuat penelitian yang bertujuan untuk mengilustrasikan secara sistematis, factual dan akurat terhadap suatu populasi. Penelitian kualitatif deskriptif ini menggunakan datadata resmi yang terdapat dalam www.idx.co.id, dan www.rti.co.id.

\section{Hasil Dan Pembahasan}

\section{Analisis Fundamental}

Tabel 1. Perbandingan Laporan Keuangan AALI dan LSIP

\begin{tabular}{|c|c|c|c|c|c|c|c|c|}
\hline & \multicolumn{4}{|c|}{ AALI } & \multicolumn{4}{|c|}{ LSIP } \\
\hline & $1^{s t}$ & $2^{\text {nd }}$ & $3^{r d}$ & $4^{\text {th }}$ & $1^{s t}$ & $2^{\text {nd }}$ & $3^{r d}$ & $4^{\text {th }}$ \\
\hline & Quarter & Quarter & Quarter & Quarter & Quarter & Quarter & Quarter & Quarter \\
\hline & 2017 & 2017 & 2017 & 2017 & 2017 & 2017 & 2017 & 2017 \\
\hline ROA & 9,49 & 9,17 & 9,09 & 8,06 & 9,32 & 9,74 & 9,82 & 7,84 \\
\hline ROE & 12,97 & 12,62 & 12,6 & 10,85 & 11,44 & 11,96 & 11,95 & 9,4 \\
\hline DPR & 44,98 & 44,98 & 44,98 & 44,98 & 40.21 & 40,21 & 40,21 & 40,21 \\
\hline DER & 0,37 & 0,38 & 0,39 & 0,35 & 0,23 & 0,23 & 0,22 & 0,2 \\
\hline $\begin{array}{l}\text { Dividend } \\
\text { Yield }\end{array}$ & 2,8 & 2,8 & 2,8 & 2,8 & 2,01 & 2,01 & 2,01 & 2,01 \\
\hline PER & 12,48 & 13,59 & 14,22 & 12,59 & 10,89 & 9,94 & 10,01 & 12,69 \\
\hline $\begin{array}{l}\text { Net } \\
\text { Profit } \\
\text { Margin }\end{array}$ & 15,33 & 13,84 & 13,32 & 11,62 & 20,36 & 20,17 & 20,0 & 16,11 \\
\hline
\end{tabular}

\section{Sumber : RTI.co.id}

Berdasarkan data dalam tabel 1, rasio profitabilitas di tahun 2017 pada perusahaan AALI dan LSIP menunjukkan performa yang sama baiknya. Sebagai contohnya angka ROA menunjukkan angka dikisaran 8,06 - 9,49 untuk AALI dan 
LSIP dikisaran 7,8 - 9,7. Angka ROE untuk AALI berada pada kisaran 10,85- 12,97, sedangkan untuk LSIP berada pada kisaran 9,4 - 11,96. Hal ini menunjukkan bahwa kedua perusahaan masih mampu mengembalikan harta dan ekuitas di tahun 2017 lebih baik dari tahun sebelumnya. Akan tetapi pada triwulan ke 4, kedua perusahaan menunjukkan penurunan nilai ROA dan ROE yang cukup besar yaitu sekitar 1-2\%. Hal ini mengindikasikan bahwa hasil pengembalian atas harta dan ekuitas pada tiga triwulan pertama tahun 2017 lebih baik daripada triwulan keempat 2017. Hal ini disebabkan karena kontribusi total aset dan ekuitas terhadap laba bersih di tahun 2016, mengalami sedikit penurunan.

Rasio solvabilitas, menunjukkan laju utang perusahaan AALI lebih tinggi dibandingkan dengan LSIP. Dalam hal ini ditunjukkan dengan nilai DER AALI yang berada dikisaran 0,35-0,39 sedangkan LSIP berada di angka 0,2-0,23. Hal ini dapat mengindikasikan bahwa adanya kemudahan bagi LSIP meminjam dana dari para kreditor karena angka DER yang lebih kecil bila dibandingkan dengan AALI.

Dalam hal rasio ukuran pasar, angka PER pada kedua perusahaan menunjukkan angka dibawah 15. Hal ini menjelaskan bahwa kedua perusahaan masih berada dalam harga yang relatif murah untuk di koleksi. Namun bila dibandingkan antara AALI dan LSIP dari sisi PER, LSIP lebih murah, karena nilai PERnya lebih rendah selama 1 tahun ini. Hal senada juga tertuang dalam Net Profit Margin (NPM) LSIP menunjukkan performa yang lebih baik dibandingkan dengan AALI, meskipun pada triwulan 4, kedua perusahaan mengalami penurunan NPM. Apabila ditinjau dari segi dividen yield dan DPR, AALI memiliki angka yang sedikit lebih besar dibandingkan LSIP. Dividen yield dan DPR dapat menarik perhatian para calon investor jika angkanya besar. Jadi dalam hal ini, AALI lebih menarik dibandingkan dengan LSIP.

Tabel 2. Perbandingan Laporan Keuangan AALI dan LSIP

\begin{tabular}{|c|c|c|c|c|c|c|c|c|}
\hline & \multicolumn{4}{|c|}{ AALI } & \multicolumn{4}{|c|}{ LSIP } \\
\hline & $1^{s t}$ & $2^{\text {nd }}$ & $3^{\text {rd }}$ & $4^{\text {th }}$ & $1^{s t}$ & $2^{\text {nd }}$ & $3^{r d}$ & $4^{\text {th }}$ \\
\hline & Quarter & Quarter & Quarter & Quarter & Quarter & Quarter & Quarter & Quarter \\
\hline & 2018 & 2018 & 2018 & 2018 & 2018 & 2018 & 2018 & 2018 \\
\hline ROA & 6,14 & 6,52 & 6,33 & 5,36 & 4,93 & 5,07 & 4,6 & 3,3 \\
\hline ROE & 8,21 & 9,25 & 9,03 & 7,39 & 6,06 & 6,48 & 5,65 & 3,98 \\
\hline DPR & 45,0 & 45,0 & 45,0 & 45,0 & 40,21 & 40,21 & 40,21 & 40,21 \\
\hline DER & 0,34 & 0,42 & 0,43 & 0,38 & 0,23 & 0,28 & 0,23 & 0,2 \\
\hline
\end{tabular}




\begin{tabular}{lrrrrrrrr}
\hline $\begin{array}{l}\text { Dividend } \\
\text { Yield }\end{array}$ & 3,57 & 3,57 & 3,57 & 3,57 & 3,17 & 3,17 & 3,17 & 3,17 \\
PER & 16,57 & 12,31 & 13,81 & 15,82 & 17,49 & 12,77 & 18,56 & 25,74 \\
& & & & & & & & \\
$\begin{array}{l}\text { Net } \\
\begin{array}{l}\text { Profit } \\
\text { Margin }\end{array}\end{array}$ & 9,07 & 9,85 & 9,3 & 7,54 & 12,19 & 13,11 & 11,61 & 8,24 \\
& & & & & & & & \\
\hline Sumber : RTI.co.id & & & & & & & &
\end{tabular}

Sumber : RTI.co.id

Di tahun 2018, secara keseluruhan rasio profitabilitas menunjukkan penurunan angka bila dibandingkan dengan tahun 2017. Hal ini menggambarkan kedua perusahaan mengalami kesulitan dalam mencetak laba. Namun apabila dibandingkan dengan kedua perusahaan ini, AALI dan LSIP, masih menunjukkan angka ROA dan ROE yang positif yaitu dikisaran angka 5,36 - 6,52 dan 7,39-9,25 untuk AALI dan LSIP di angka 3,3 - 5,07 dan 3,98 - 6,48. Penurunan yang cukup signifikan ini tidak terlepas dari harga Crude Palm Oil yang terus menerus menurun dan berkurangnya permintaan ekspor.

Pada rasio kelancaran pembayaran utang di tahun 2018, kedua perusahaan tidak menunjukkan perubahan angka rasio DER yang meningkat tajam. Terlihat dalam rasio DER AALI yang mengalami peningkatan dari tahun 2017 ke 2018, dari angka dikisaran 0,37 menjadi 0,4. Sedangkan LSIP masih berada di rentang yang relatif stabil 0,23. Nilai DER yang lebih rendah mengindikasikan perusahaan memiliki kemampuan untuk membayar hutang lebih baik dibandingkan dengan nilai DER yang tinggi. Dalam Hal ini, LSIP lebih layak dipertimbangkan daripada AALI.

Dalam rasio ukuran pasar, kedua perusahaan menunjukkan kenaikan angka PER dari tahun 2017 ke 2018. Terlebih lagi angka PER untuk AALI dan LSIP sudah menunjukkan lebih besar dari angka 15, sehingga AALI dan LSIP masuk dalam kategori saham yang memiliki harga yang overbought, karena banyak orang yang membeli saham tersebut, sehingga harga sahamnya naik daripada nilai wajarnya. Nilai PER yang lebih tinggi mengindikasikan saham berharga mahal untuk dikoleksi, sehingga dalam hal ini saham AALI lebih layak untuk dikoleksi daripada LSIP. Berbeda halnya bila ditinjau dari angka NPM, LSIP memiliki nilai NPM yang lebih besar dibandingkan dengan AALI, sehingga LSIP lebih layak dipertimbangkan sebelum berinvestasi. Dari sisi DPR dan dividend yield, angka yang dimiliki AALI 
sedikit lebih besar dibandingkan dengan LSIP. Hal ini dapat sebagai faktor pertimbangan juga sebelum memilih saham AALI dari LSIP.

Tabel 3. Perbandingan Laporan Keuangan AALI dan LSIP

\begin{tabular}{lcccc}
\hline & \multicolumn{3}{c}{ AALI } & \multicolumn{2}{c}{ LSIP } \\
& $1^{\text {st }}$ Quarter & $2^{\text {nd }}$ Quarter & $1^{\text {st }}$ Quarter & $2^{\text {nd }}$ Quarter \\
& 2019 & 2019 & 2019 & 2019 \\
\hline ROA & 4,17 & 2,57 & 2,46 & 1,15 \\
ROE & 5,75 & 3,68 & 3,03 & 1,42 \\
DPR & 45,0 & 45,0 & 40,21 & 40,21 \\
DER & 0,38 & 0,43 & 0,23 & 0,24 \\
Dividend & 3,57 & 3,57 & 3,17 & 3,17 \\
Yield & & & & \\
PER & 19,28 & 28,66 & 27,93 & 65,34 \\
& & & & \\
Net profit & 5,94 & 3,76 & & \\
Margin & & & & \\
& & & &
\end{tabular}

Sumber : RTI.co.id

Pada tahun 2019, secara keseluruhan angka rasio profitabilitas dan ukuran pasar menunjukkan penurunan yang cukup tinggi bila dibandingkan dengan tahun 2017 dan 2018. Hal ini tertuang dalam angka ROA, ROE, dan NPM. Dengan menurunnya ketiga rasio tersebut maka secara tidak langsung akan berdampak pada rasio lainnya seperti PER yang semakin tinggi. Nilai PER yang sangat tinggi, menandakan bahwa antusias para investor dalam berinvestasi kepada kedua saham ini masih sangat tinggi, meskipun profitabilitas yang dihasilkan oleh kedua perusahaan ini tergolong rendah. Jadi, berdasarkan data tahun 2019, AALI lebih layak dipertimbangkan untuk diburu para calon investor, karena memiliki performa yang lebih unggul. Sedangkan dari nilai DER menunjukkan angka rasio utang AALI lebih besar daripada LSIP, yaitu dikisaran angka 0,4 untuk AALI dan LSIP 0,235. Hal ini menunjukkan bahwa LSIP lebih mampu mengembalikan utang terhadap ekuitas sehingga LSIP bila ingin meminjam dana akan lebih mudah dan dipercaya oleh Bank yang meminjam dibandingkan dengan AALI. 


\section{Analisis Teknikal}

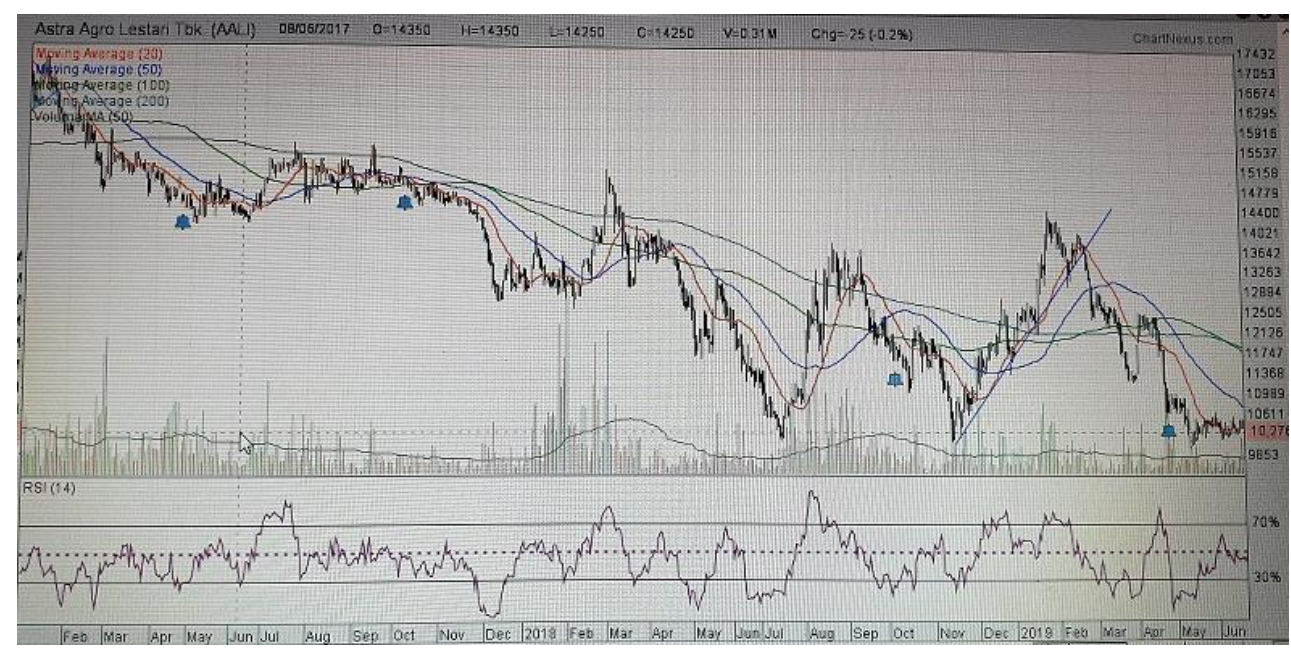

Grafik 1. Pergerakan Harga Penutupan Saham AALI 2017 - Semester 12019

Berdasarkan Grafik 1, pada awal tahun 2017 terjadi penurunan kurva penutupan harga saham AALI, yang ditandai dengan adanya penurunan garis Moving Average 20 (MA20) yang terus menurun kebawah sampai pada bulan awal bulan Juli 2017. Garis MA 20 berhasil melakukan breakout dengan menembus garis MA50,100 dan 200 sejak bulan Juli sampai November 2017. Namun terjadi pelemahan pad garis MA 20 yang cenderung menurun terlebih setelah terbaginya dividen sekitar bulan Oktober 2017. Penurunan harga saham berlanjut sampai dengan bulan Februari 2018. Pada bulan Februari 2018, terjadi koreksi akibat dari bearish reversal sejak Desember 2018. Hal senada juga didukung oleh grafik RSI yang undervalue sejak desember 2017, namun menjadi overvalued pada bulan Februari 2018. Pada kuartal III ke IV, penurunan harga saham menjadi yang paling rendah sejak tahun 2017, hal ini membentuk pola..... Sedangkan pada bulan Agustus September 2018, saham AALI mengalami koreksi dari akibat penurunan saham yang sangat tajam.

Pada bulan November 2018 - Februari 2019, terjadi pembalikan arah menuju bullish. Dari indicator RSI telah menunjukkan harga saham AALI yang sudah undervalue atau murah untuk dibeli sejak November. Dibulan Februari 2019, saham AALI sudah mengalami overbought sehingga sudah terlalu mahal untuk dibeli. Dari bulan Ferbuari - akhir maret 2019, Garis MA 20 belum mampu menembus garis support, sehingga terjadi penurunan atau koreksi sampai bulan April 2019. Dari 
bulan akhir April- Juni 2019 terjadi penurunan harga saham yang tajam, sebagai hasil dari buruknya laporan keuangan yang muncul pada kuartal I 2019.

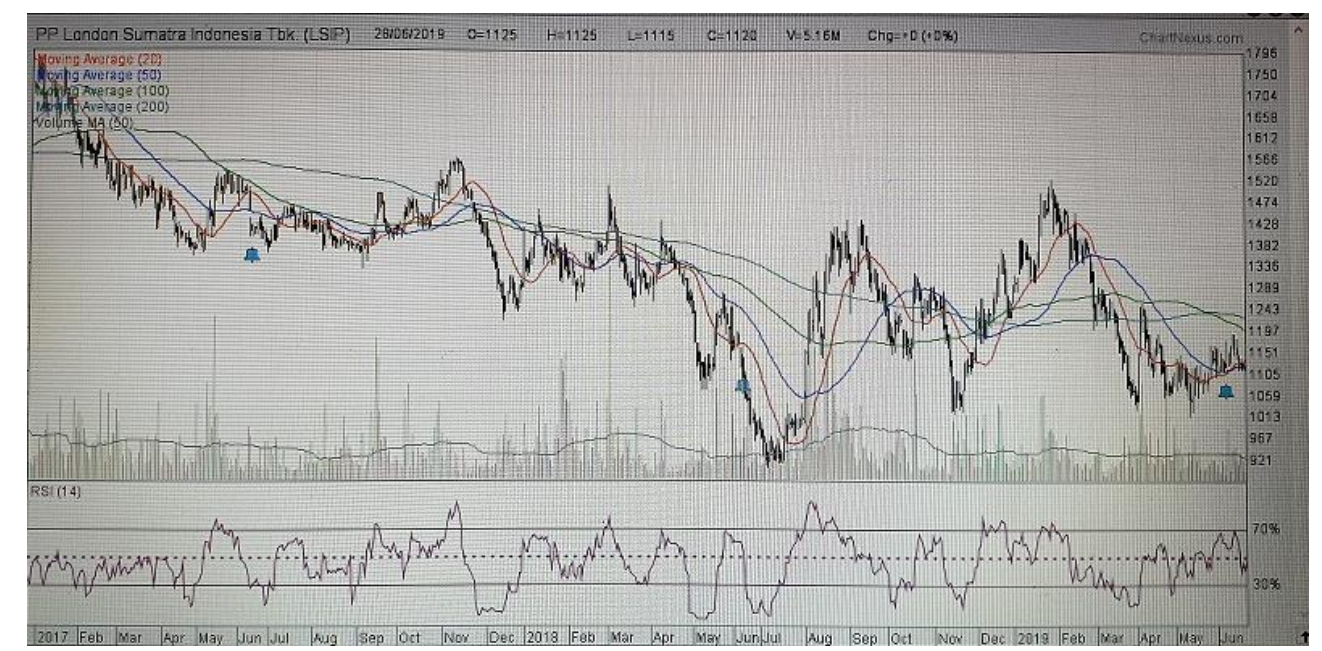

Grafik 2. Pergerakan Harga Penutupan Saham LSIP 2017 - Semester 12019

Berdasarkan data Grafik 2, di kuartal I 2017, saham LSIP mengalami penurunan harga yang cukup signifikan, meskipun kabar yang beredar adalah laba perusahaan pada laporan keuangan meningkat. Hal ini ditunjukkan oleh kedua indicator RSI yang undervalued dan garis MA 20 yang cenderung di posisi bearish. Selama bulan April - Juni 2017, saham bergerak naik sebagai akibat koreksi penurunan saham yang cukup tinggi. Pada kuartal II saham bergerak sideways setelah pengumuman jadwal pembagian dividen tunai. Di kuartal III sampai bulan November 2017, harga saham bergerak bearish reversal sementara sebagai dampak dari terbitnya laporan keuangan kuartal II yang mencatatkan posisi kenaikan laba. Namun pada bulan November - awal Januari 2018, harga saham cenderung melemah. Di kuartal 1 2018, harga saham LSIP cenderung dalam kondisi sideways. Sedangkan pada kuartal II terjadi pergejolakan harga yang cukup besar sehingga menyebabkan indikator RSI menilai saham mengalami undervalued. Penurunan harga saham disebabkan karena munculnya laporan keuangan yang negatif terhadap arus NPM bila dibandingkan yoy tahun sebelumnya.

Pada kuartal III 2018, saham mengalami kenaikan harga, atau bullish yang cukup tinggi, dan kenaikan ini bertahan sampai awal September 2018. Di bulan September - awal bulan Desember 2018, harga saham mengalami bullish reversal, yang cukup dalam lagi. Pada awal bulan Desember 2018 - Februari 2019 saham 
bergerak naik, hal ini didukung oleh perpotongan garis MA 20 pada bulan Desember yang terus meningkat dan mampu menembus garis MA 50,100 dan 200. Namun sampai pada bulan Februari 2019, saham mengalami koreksi kembali. Pada bulan Februari - Juni 2019, pergerakan harga saham dalam kondisi stagnan atau sideways.

Tabel 4. Berita yang Berdampak pada Harga Saham AALI

\begin{tabular}{|c|c|c|c|c|}
\hline No. & Tanggal & Fakta atau Kebijakan & $\begin{array}{l}\text { Dampak terhadap } \\
\text { Perusahaan }\end{array}$ & $\begin{array}{l}\text { Harga Penutupan } \\
\text { saham dari hari } \\
\text { sebelumnya. }\end{array}$ \\
\hline 1. & $\begin{array}{l}28 \text { Februari } \\
2017\end{array}$ & $\begin{array}{l}\text { Pendapatan } \text { AALI } \\
\text { meningkat } 8 \% \text { dari } \\
\text { Rp.13,06 T menjadi } \\
\text { Rp. } 14,12 \mathrm{~T} \text {. }\end{array}$ & $\begin{array}{l}\text { Salah satu } \\
\text { penyebab } \\
\text { melonjaknya } \\
\text { pendapatan } \\
\text { perusahaan adalah } \\
\text { keuntungan } \\
\text { selisih kurs dan } \\
\text { menyusutnya } \\
\text { beban pajak } \\
\text { penghasilan dari } \\
\text { 479,83 M menjadi } \\
\text { Rp. } 94,48 \mathrm{M} \text {. }\end{array}$ & $\begin{array}{l}\text { Menurun } \text { dari } \\
\text { harga Rp. } 15.800 \\
\text { ke harga Rp. } \\
14.950 \text { per lembar } \\
\text { saham. }\end{array}$ \\
\hline 2. & 11 April 2017 & 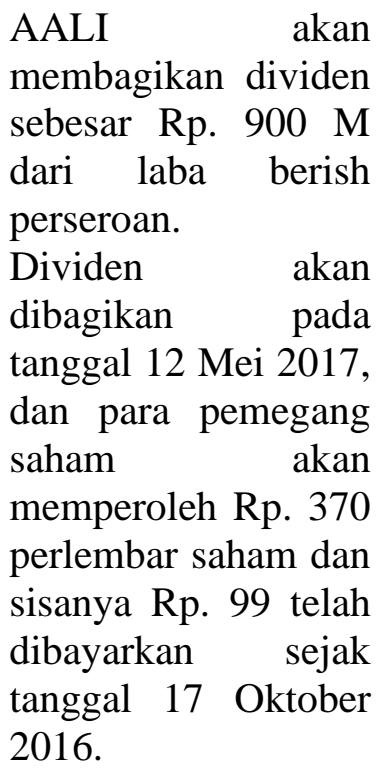 & $\begin{array}{l}\text { AALI akan } \\
\text { membagikan } \\
\text { dividen sekitar } \\
45 \% \text { dari laba } \\
\text { bersih atau setara } \\
\text { dengan Rp. } 469 \\
\text { perlembar saham. }\end{array}$ & $\begin{array}{l}\text { Menurun dari } \\
\text { harga Rp. } 14.575 \\
\text { ke harga Rp. } \\
14.500 \text { per lembar } \\
\text { saham. }\end{array}$ \\
\hline 3. & $\begin{array}{l}08 \text { Agustus } \\
2017\end{array}$ & $\begin{array}{lr}\text { AALI mencatatkan } \\
\text { peningkatan produksi } \\
\text { CPO sebesar } & 13,7 \% \text {. } \\
\text { Kenaikan } & \text { ini, } \\
\text { didukung juga } & \text { jengan peningkatan } \\
\text { dengan } & \text { produksi Tandan } \\
\text { Buah Segar (TBS) } & \text { (Ther } \\
23,1 \% \text { menjadi } & 2,5\end{array}$ & $\begin{array}{l}\text { Produksi } \quad \text { CPO } \\
\text { perusahaan } \text { AALI } \\
\text { meningkat ke } \\
\text { angka } 762.000 \text { ton } \\
\text { dari periode } \\
\text { sebelumnya tahun } \\
2017 \text { di angka } \\
670.000 \text { ton. }\end{array}$ & $\begin{array}{l}\text { Meningkat dari } \\
\text { harga Rp. } 15.050 \\
\text { ke harga Rp. } \\
15.300 \text { per lembar } \\
\text { saham. }\end{array}$ \\
\hline
\end{tabular}




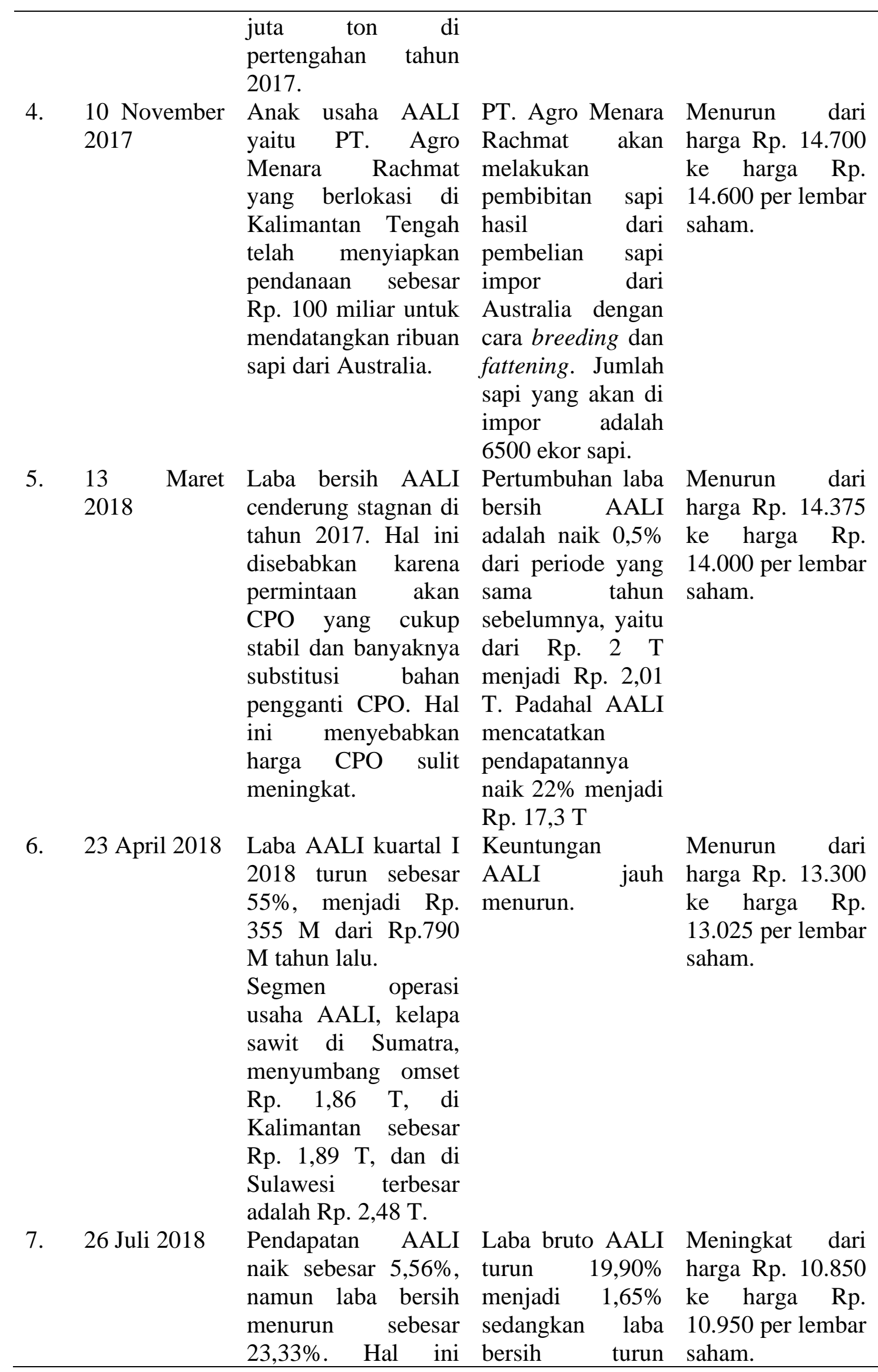




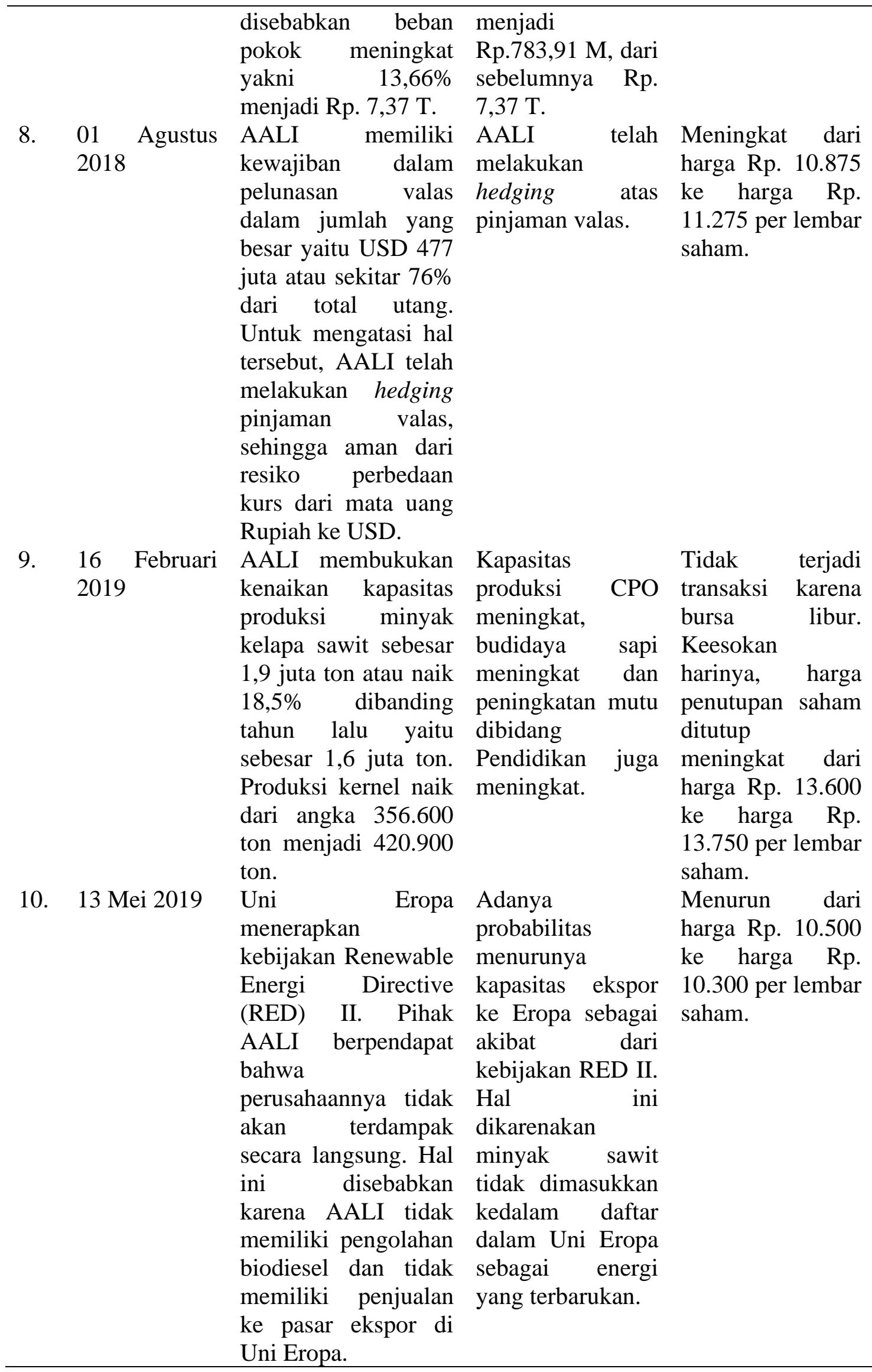


Berdasarkan pada Tabel 4, fakta atau kebijakan terhadap harga penutupan saham, di tahun 2017 pergerakan harga saham berbanding terbalik dengan fakta atau kebijakan yang beredar. Hal ini mengindikasikan bahwa pasar bereaksi negatif terhadap berita yang tersiar di media. Pasar meyakini bahwa aksi korporasi yang sudah dan akan dilaksanakan tidak akan berdampak signifikan terhadap laporan keuangan perusahaan secara tidak langsung. Di tahun 2018, tersiar kebijakan baru bahwa terjadi penurunan permintaan dari negara luar, sehingga berdampak pada ekspor CPO. Seperti hukum permintaan dan penawaran, permintaan berkurang maka harga CPO dunia juga menurun. Upaya positif perusahaan terus dilakukan untuk membukukan kenaikan laba di tahun 2018 - pertengahan 2019, seperti dengan meningkatkan kapasitas produksi CPO dan melakukan hedging atas pinjaman valas, namun segala upaya tersebut tidak dapat meningkatkan laba perusahaan. Hal ini berbanding lurus dengan penurunan harga saham.

Tabel 5. Berita yang Berdampak pada Harga Saham LSIP

\begin{tabular}{|c|c|c|c|c|}
\hline No. & Tanggal & Fakta atau Kebijakan & $\begin{array}{l}\text { Dampak terhadap } \\
\text { Perusahaan }\end{array}$ & $\begin{array}{l}\text { Harga Penutupan } \\
\text { saham dari hari } \\
\text { sebelumnya. }\end{array}$ \\
\hline 1. & $\begin{array}{l}2 \\
2017\end{array}$ & $\begin{array}{l}\text { Pengaruh El Nino } \\
\text { mempengaruhi laju } \\
\text { kinerja LSIP. Hal ini } \\
\text { berdampak pada laba } \\
\text { bersih LSIP turun } \\
4,9 \% \text { di tahun } 2016 .\end{array}$ & $\begin{array}{l}\text { Laba bersih } 2016, \\
\text { LSIP menurun } \\
\text { akibat dari El } \\
\text { Nino }\end{array}$ & $\begin{array}{l}\text { Meningkat dari } \\
\text { harga Rp. } 1540 \text { ke } \\
\text { harga Rp. } 1545 \\
\text { per lembar saham. }\end{array}$ \\
\hline 2. & 1 Juni 2017 & $\begin{array}{l}\text { LSIP membagikan } \\
\text { dividen Rp. } 35 \\
\text { perlembar } \\
\text { dengan nilai Dividen } \\
\text { Payout Ratio (DPR) } \\
\text { sebesar } 40 \% \text { dari laba } \\
\text { bersih. Besaran DPR } \\
\text { tahun } 2016 \text { tersebut } \\
\text { sama dengan besaran } \\
\text { DPR } \\
\text { sebelumnya. tahun }\end{array}$ & $\begin{array}{l}\text { LSIP } \\
\text { membagikan } \\
\text { dividen dari laba } \\
\text { bersih tahun } 2016 \\
\text { sebesar } 40 \% \text { dari } \\
\text { total laba bersih } \\
\text { Rp. } 593,83 \mathrm{M} \text {. }\end{array}$ & $\begin{array}{lr}\text { Tidak } & \text { terjadi } \\
\text { transaksi } & \text { karena } \\
\text { bursa libur. } & \text { Pada } \\
\text { Keesokan } & \\
\text { harinya, harga } \\
\text { penutupan ditutup } \\
\text { menurun dari } \\
\text { harga Rp. } & 1.515 \\
\text { ke harga Rp. } \\
1.490 \text { per lembar } \\
\text { saham. }\end{array}$ \\
\hline 3. & $\begin{array}{l}27 \quad \text { Oktober } \\
2017\end{array}$ & $\begin{array}{l}\text { Laba perusahaan LSIP } \\
\text { periode Januari - } \\
\text { September } 2017 \text {, } \\
\text { dicatat positif yaitu }\end{array}$ & $\begin{array}{l}\text { Peningkatan } \\
\text { penjualan } \\
\text { terlaksana di } \\
\text { semua segmen }\end{array}$ & $\begin{array}{lr}\text { Meningkat } & \text { dari } \\
\text { harga Rp. } & 1.510 \\
\text { ke harga } & \text { Rp. } \\
1.515 \text { per lembar }\end{array}$ \\
\hline
\end{tabular}




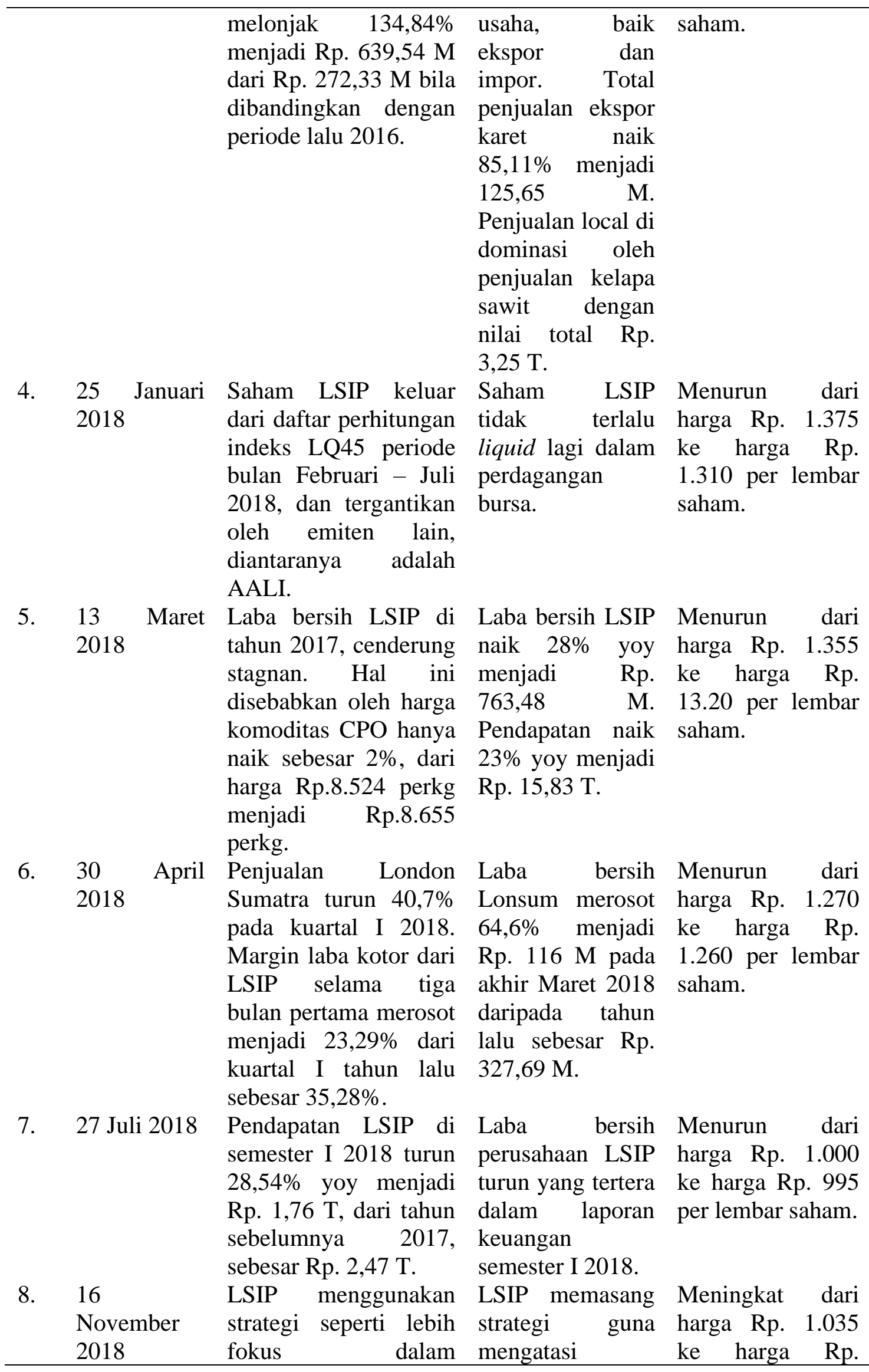




\begin{tabular}{|c|c|c|c|c|}
\hline & & $\begin{array}{l}\text { meningkatkan } \\
\text { produktivitas kebun }\end{array}$ & $\begin{array}{l}\text { penurunan harga } \\
\text { jual CPO }\end{array}$ & $\begin{array}{l}1.050 \text { per lembar } \\
\text { saham. }\end{array}$ \\
\hline & & dan melakukan & & \\
\hline & & efisiensi biaya. Selain & & \\
\hline & & itu, LSIP juga & & \\
\hline & & mengejar target & & \\
\hline & & produksi CPO yang & & \\
\hline & & meningkat $12 \%$ dari & & \\
\hline & & tahun 2017. & & \\
\hline 9. & 28 Februari & Laba bersih London & Jumlah kapasitas & Menurun dari \\
\hline & 2019 & Sumatra turun $54,81 \%$ & produksi & harga Rp. 1.255 \\
\hline & & $\begin{array}{l}\text { yoy dari tahun } \\
\text { sebelumnya dari Rp. } \\
\text { 733,31 M menjadi Rp. } \\
\text { 311,36 M. }\end{array}$ & $\begin{array}{l}\text { meningkat namun } \\
\text { total penjualan } \\
\text { dan laba bersih } \\
\text { emiten }\end{array}$ & $\begin{array}{l}\text { ke harga Rp. } \\
1.220 \text { per lembar } \\
\text { saham. }\end{array}$ \\
\hline & & $\begin{array}{l}\text { Hal ini disebabkan } \\
\text { karena }\end{array}$ & menurun. & \\
\hline & & $\begin{array}{l}\text { harga jual rata-rata } \\
\text { produk CPO dan karet. }\end{array}$ & & \\
\hline 10. & 6 Mei 2019 & Kinerja LSIP menurun & Laba menurun & Menurun \\
\hline & & di kuartal I 2019, yang & akibat harga jual & harga Rp. 1.130 \\
\hline & & berdampak pada laba & yang menurun. & ke harga $\mathrm{Rp}$. \\
\hline & & bersih yang menurun & & 1.100 per lembar \\
\hline & & sebesar $66,7 \%$ menjadi & & saham. \\
\hline & & Rp. 38,62 M, dari Rp. & & \\
\hline & & $115,99 \quad \mathrm{M}$ tahun & & \\
\hline & & sebelumnya. & & \\
\hline
\end{tabular}

Berdasarkan data Tabel 5, harga saham LSIP di tahun 2017, bergerak seirama dengan harga saham. Sebagai contohnya adalah pada tanggal 27 Oktober 2017, Laba perusahaan dikuartal III 2017 meningkat, hal ini disambut pasar secara positif dengan meningkatnya harga saham. Di tahun 2018, seperti halnya dengan AALI, perusahaan berkodekan LSIP ini juga menunjukkan senada dengan berita yang beredar. Harga saham LSIP bergerak menurun, seiring dengan munculnya berita tentang laba yang menurun pada laporan keuangan. Pada tanggal 16 November 2018, tersiar kabar bahwa LSIP mengupayakan strategi untuk mengatasi penurunan laba dengan cara meminimalkan biaya operasional dan meningkatkan kapasitas produksi CPO. Namun hal ini masih belum juga dapat mengatasi laju penurunan laba LSIP. Sampai pada pertengahan tahun 2019, masih belum ada tanda-tanda bahwa harga CPO akan mengalami peningkatan, sehingga diperkirakan laporan keuangan LSIP akan cenderung stagnan atau turun bila dibandingkan dengan tahun 2018, yang 
berdampak juga kaburnya para investor yang ditunjukkan dengan penurunan harga saham LSIP dilantai bursa.

\section{Kesimpulan, Implikasi, Saran dan Keterbatasan}

Berdasarkan pemaparan diatas, pada tahun 2017 perusahaan AALI dan LSIP menunjukkan performa kinerja laporan keuangan yang prima yang didukung oleh data fundamental perusahaan yang baik. Salah satu faktor utama penyebab primanya kinerja perusahaan adalah harga dan permintaan CPO dunia meningkat. Alhasil AALI dan LSIP mampu meningkatkan produksi dan menjual hasil produksi baik didalam negri maupun ekspor. Hal ini juga di tunjukkan dengan data historis teknikal, yang menjelaskan bahwa adanya peningkatan jumlah volume dan frekuensi perdagangan yang berdampak pada garis RSI dan MA yang bergerak kearah uptrend. Fakta dan kebijakan yang dilaksanakan oleh perusahaan tidak menunjukkan keselarasan dengan kenaikan dan penurunan harga saham. Dalam hal ini, fakta yang berasal dari internal dan eksternal tidak dapat menjadi faktor pendukung bagi pergerakan harga saham itu sendiri.

Berbeda halnya dengan tahun 2018 - pertengahan 2019, munculnya berita akan penurunan permintaan ekspor minyak kelapa sawit, maka akan berdampak pada penurunan laba kedua perusahaan. Dari sisi fundamental akan terkena imbas terlebih dahulu terutama dari hal rasio profitabilitas. Dengan buruknya laporan keuangan, hal ini juga berdampak pada penurunan minat investor dalam membeli saham perkebunan kelapa sawit ini. Hal ini ditunjuang juga dari sisi teknikal yang dibuktikan dengan garis MA yang terus menurun, yang menyebabkan RSI terhadap kedua perusahaan undervalue.

Jadi kedua perusahaan minyak kelapa sawit ini menunjukkan performa kinerja yang cukup bagus dalam menghadapi tekanan penurunan harga CPO dan pengurangan permintaan negara ekspor, dalam mencetak laba. Namun, secara keseluruhan saham AALI lebih layak untuk di investasikan dibandingkan dengan LSIP.

\section{Referensi}

Chen, J. (2018). Technical Analysis Basic Education. www.investopedia.com. Corrado, C. J. dan Bradford D. Jordan. (2002). Fundamentals of Investments Valuation \& Management. New York : McGraw-Hill 
Kang, H. \& Petzke, S., (2009), Study Guide To Accompany Accounting. Australia: Wiley and Sons.

Ong, E. (2008). Technical Analysis for Mega Profit. Jakarta: Mega Options.

Supardi. (2005). Metodologi Penelitian Ekonomi dan Bisnis. Yogyakrta: UII Press.

Santosa, W.P. (2010). Analisa Kerja Fundamental dan Persepsi Pasar PT. Argo

Lestari, Tbk. Jurnal Dikta Ekonomi. ISSN 1411-0776.

Tandelilin, E. (2010). Portofolio dan Investasi Teori dan Aplikasi. Edisi kedua.Yogyakarta: Kanisius. 